\title{
Review Paper: The Role of Digital Technologies as an Alternative for Face-to-Face Knee Rehabilitation: A Systematic Review
}

\author{
Farzaneh Saki $^{1 *} \mathbb{1}$, Shima Bakhtiari Khou ${ }^{1} \mathbb{C}$, Farzaneh Ramezani' $\mathbb{C}$ \\ 1. Department of Corrective Exercises and Sport Injury, Faculty of Sport Sciences, Bu-Ali Sina University, Hamadan, Iran.
}

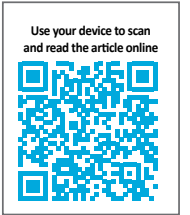

Citration Saki F, Bakhtiari Khou S, Ramezan F. The Role of Digital Technologies as an Alternative for Face-to-Face Knee Rehabilitation: A Systematic Review. Physical Treatments. 2020; 10(4):185-194. http://dx.doi.org/10.32598/ptj.10.4. 433.2

: http://dx.doi.org/10.32598/ptj.10.4. 433.2

\section{(i) (5)}

Article info:

Received: 10 Jun 2020

Accepted: 22 Aug 2020

Available Online: 01 Oct 2020

Keywords:

Osteoarthritis, Knee arthroplasty, Technology, Fitness trackers

\section{A B S T RA C T}

Purpose: Digital technologies, including mobile applications, websites, and wearable devices, like smartwatches are among the newest approaches in prevention, care, and treatment studies; they could provide public access to high-quality rehabilitation services. The current review study aimed to evaluate the effects of digital technologies for enhancing physical activity, as well as improving and managing pain in individuals with knee injuries and pain.

Methods: The keywords "digital care program", “e-health", "physical activity", and "knee pain" were used to search the studies in the PubMed, Scopus, and Google Scholar databases. In total, 734 articles were found. Then, studies published in languages other than English; the articles with completely similar results; the studies on diseases other than knee problems, and those investigating children or adolescents were excluded. Thus, valid articles indexed in these databases that digital technologies were an except original in the intervention; databases that investigated the impact of digital technologies on osteoarthritis and total knee arthroplasty knee improvement, and the randomized controlled trials were included in this research. Eventually, 8 articles were evaluated in this study. The methodological quality of the studies was assessed using the PEDro score.

Results: The overall outcome of the explored studies indicated that digital technologies significantly impact pain relief, and improve mobility, quality of life, and self-care in patients with osteoarthritis and total knee arthroplasty.

Conclusion: Digital technologies increase the effectiveness of rehabilitation programs and play an essential role in creating a self-care culture. These technologies have resulted in savings in medical, commuting, pharmacotherapy, and surgery costs by communicating between patient and therapist at any time in any place.

\footnotetext{
* Corresponding Author:

Farzaneh Saki, PhD.

Address: Department of Corrective Exercises and Sport Injury, Faculty of Sport Sciences, Bu-Ali Sina University, Hamadan, Iran Phone: +98 (918) 8503783

E-mail:f_saki@basu.ac.ir
} 


\section{Highlights}

- Digital technologies are one of the newest approaches used in the field of prevention, care, and treatment.

- Digital technologies provide opportunities for home rehabilitation by empowering the patients that can help with reducing costs.

- The use of digital technologies provides significant improvement in motor parameters and reduces pain in patients with knee OA and TKA.

\section{Plain Language Summary}

OA is the most common progressive articular injury. Knee osteoarthritis causes pain and decreased physical activity. Up to now, no definitive cure has been identified for OA and only the required measures have been taken to manage it. Exercise at home can improve the pain, mobility, and quality of life of people with OA. Patient self-care is an important factor for managing OA and post-TKA care, for which the use of digital technologies are helpful in this regard. Exercise therapy through DVDs, websites, or video software on mobiles allows patients to exercise comfortably in their homes while watching a sports show. In addition, remote sensing technologies enable monitoring of patients adherence leading to individual and timely interventions during treatment, a major barrier that limits the effectiveness of long-term treatment programs.

\section{Introduction}

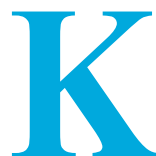

nee Osteoarthritis (OA) is the most frequent articular disorder. Its prevalence is approximately $45 \%$ in the general population $(40 \% \& 47 \%$ for men $\&$ women, respectively). Knee OA is among the 5 main causes of disability in adults over 50 years of age [1]. Besides, it is a significant threat to their Quality of Life (QoL) and independence. Previous studies have suggested that OA affects about $14 \%$ of individuals aged $>26$ years, $27 \%$ of adults aged $>45$ years, and $37 \%$ of adults aged $>60$ years [2].

Knee OA causes pain and decreased physical activity, which adversely affects the patient's QoL $[3,4]$. No definitive cure has been identified for and only the required measures have been taken to manage it. The optimal management of knee OA requires a combination of pharmacological (e.g., corticosteroids, topical analgesia, \& intraarticular therapy) and non-pharmacological (e.g., weight loss, exercise, \& physical activity) therapies $[5,6]$. Total Knee Arthroplasty (TKA) is necessary when the conservative treatments of knee OA, such as physiotherapy, weight loss, physical activity, exercise, patient training [7], intraarticular injection, and anti-inflammatory medications are ineffective [6]. The incidence of TKA has increased by $56 \%$ in 2020 [8]. It is estimated that the demand for TKA will rise by $673 \%$ until 2030 [9].
The benefits of TKA are negligible due to its side effects for the patients treated with TKA. Numerous studies have reported that long-term rehabilitation is critical to facilitate muscle strength recovery, the range of motion, walking, and proprioception, and improve kinematics during dynamic activities, and daily living activities [10, 11]. Therefore, postoperative rehabilitation is an essential complement to surgery. It is also a necessary component of returning to optimal functional levels in patients with TKA.

Among conservative treatments, exercise therapy generates the least adverse effects on the internal organs of the body; it can be practiced anywhere, anytime, and at a low cost [12]. In addition, home exercise therapy is effective for improving the patient's walking ability and daily living activities. This is due to improved joint stability, muscle strength, and range of motion [4]. Based on the literature, patients with knee OA who walk $\geq 6000$ steps per day encounter less functional limitations, compared to their sedentary counterparts [13]; thus, walking can maintain knee function and reduce the complications of this disease.

Digital technologies are among the newest approaches used in the field of prevention, care, and treatment. There were more than two billion smartphones and 287000 lifestyle applications on the Google Play Store in 2020; such data demonstrate the strong influence of digital technologies on human life [14]. Digital technologies can be a 
cost-effective alternative to in-person treatment sessions, where the lifestyle changes, follow-up, and guidance of patients are addressed. These technologies are easily accessible via smartphones and smartwatches, email, websites, webcams, and remote monitoring sensors.

Besides, remote sensing technologies enable the monitoring of patients' adherence to treatment, leading to individual and timely interventions during treatment; it is a major barrier that limits the effectiveness of long-term treatment programs [15]. Patient self-care is important for managing OA and post-TKA care; accordingly, applying digital technologies is helpful. Digital technologies provide opportunities for home rehabilitation by empowering the patients that can assist with reducing costs. Such applications have demonstrated clinical pain relief over the past 5 years. They have also resulted in saving medical costs due to reduced need for injections, medications, and surgery.

Digital health is moving to many different areas of healthcare, including Cognitive-Behavioral Therapy (CBT) for pain and depression, and the remote monitoring of patients with cardiovascular disease [16]. A digital health program has reflected positive results in the prevention of diabetes; the outcomes continue for up to two years after the completion of the program [17]. Similarly, the effects of a digital sleep therapy program have been established in a randomized controlled trial [18]. However, there is relatively limited digital innovation in the musculoskeletal field and it has rarely been studied in this context.

A certain treatment for OA remains undiscovered; thus, patients usually reported functional limitations and pain after TKA [19]. According to the significance of knee rehabilitation in the return to optimal functional levels and advantages of non-face rehabilitation, the current review aimed to evaluate the effects of digital technologies for enhancing physical activity, improving, and managing pain in patients with knee injuries and pain.

\section{Materials and Methods}

A systematic search was conducted from October 2019 to January 2020 in the PubMed, Scopus, and Google Scholar databases. The used keywords included "digital care program", "e-health", "physical activity", and "knee pain". This review study only considered articles that have directly studied knee treatment and rehabilitation programs through various digital technologies. The studies published in languages other than English; those on diseases other than knee problems; the articles with com-

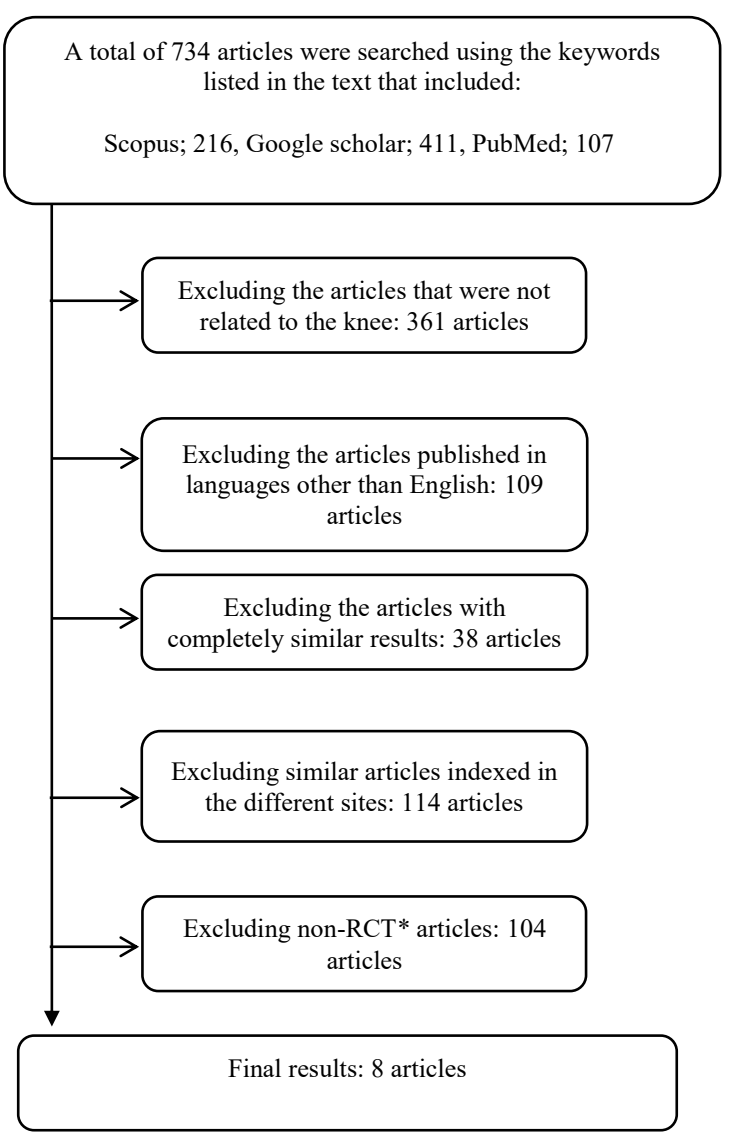

Figure 1. The PRISMA diagram

PHYSICAL TREA MENTS

*RCT: Randomized Controlled Trial.

pletely similar results, and those investigating children or adolescents were excluded. The inclusion criteria were as follows: valid articles indexed in these databases that digital technologies were an except original in the intervention; databases that investigated the impact of digital technologies on OA and TKA knee improvement, and the randomized controlled trials (Table 1).

\section{Results}

A total of 734 articles were found based on the search strategies of this study. Then, the title and abstract of the articles were evaluated considering the inclusion and exclusion criteria of the study. Finally, 8 articles were remained and assessed based on the full-text evaluation of the articles. Figure 1 shows the exclusion algorithm of the explored papers.

The studies evaluated in this review were randomized controlled trials that had examined the impact of digital technologies on the improvement of knee problems. Furthermore, most reviewed articles were focused on individuals with knee OA, and only 3 studies focused on 
Table 1. Evaluating the studies according to the PED ro scale

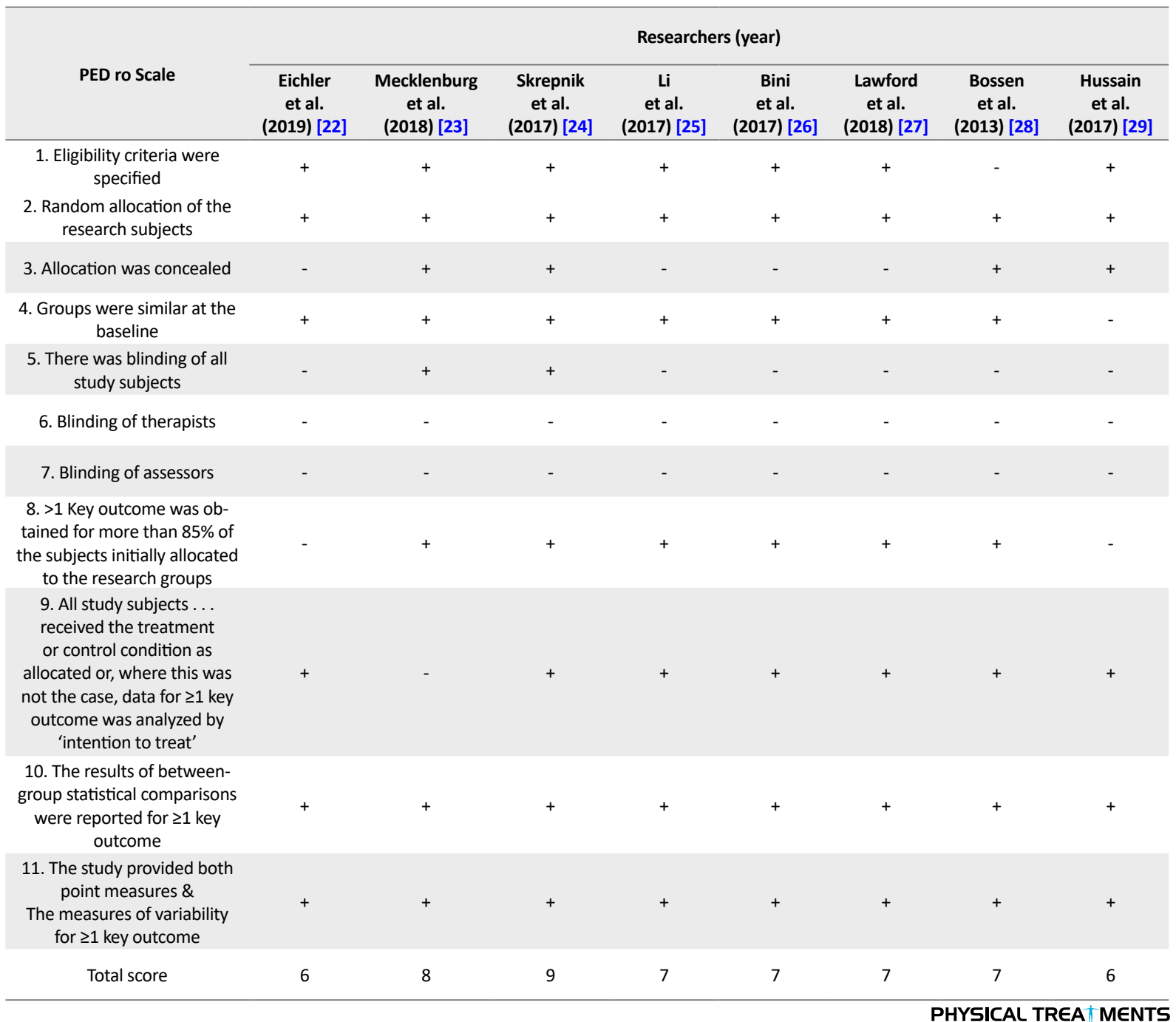

TKA. The study participants included 1101 males and females. These interventions were performed to reduce pain, stiffness, Body Mass Index (BMI), and surgical risk, as well as to increase physical activity and QoL. The research participants' age ranged 18-80 years, with the intervention period ranging 2-12 weeks.

The technologies used in the selected studies included mobile applications, activity trackers, and websites. The explored participants received relevant programs and exercises through a website in two studies; activity trackers were used alone in one study; rehabilitation was conducted through smartphone applications in the 3 other studies. A combination of digital technologies was employed in other articles. Most evaluated investigations had used consultants or supporters to motivate and maintain the treatment process. The interventions of control groups varied in different studies (Table 2).
To evaluate the quality of the methodology, the PEDro scale was used for randomized studies [20]. The score of each study was determined by two authors. The PEDro scale includes 11 items, and the first item evaluates external validity. This item is usually not included in the study evaluation. Thus, the evaluation was performed based on items 2-12 in the present study according to Moher et al.'s (2015) guidelines. Score one was given for the option "yes" and the score zero was dedicated to the option "no". The studies with this scale ranged from zero to 4 , as poor methodological quality, 6 or 6 as moderate, and those with scores of $\geq 7$ had high methodological quality [21].

\section{Discussion}

Digital technologies can effectively provide knee selfcare (chronic pain) programs. The patients with OA may have trouble performing moderate to severe activities due to pain [30]. In this situation, individuals can perform light 
Table 2. Details of the explored articles

\begin{tabular}{|c|c|c|c|c|c|c|c|c|}
\hline 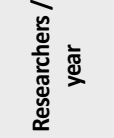 & Statistical Society & $\begin{array}{l}\text { Statis- } \\
\text { tical } \\
\text { Sample }\end{array}$ & Study Period & $\begin{array}{l}\text { Technology } \\
\text { Type }\end{array}$ & $\begin{array}{l}\text { Consul- } \\
\text { tant/Sup- } \\
\text { porter }\end{array}$ & $\begin{array}{l}\text { Experimental } \\
\text { Group Interven- } \\
\text { tions }\end{array}$ & $\begin{array}{l}\text { Control } \\
\text { Group } \\
\text { Interven- } \\
\text { tions }\end{array}$ & Results \\
\hline $\begin{array}{l}\text { Eichler et } \\
\text { al. (2019) } \\
\text { [22] }\end{array}$ & $\begin{array}{l}\text { Individuals with } \\
\text { total knee and hip } \\
\text { arthroplasty }\end{array}$ & $\begin{array}{l}111 \\
\text { sub- } \\
\text { jects }\end{array}$ & 3 months & $\begin{array}{l}\text { MeineReha } \\
\text { System }\end{array}$ & $\begin{array}{l}\text { Supervising } \\
\text { therapist }\end{array}$ & $\begin{array}{l}\text { Receiving training } \\
\text { program through } \\
\text { the system by a } \\
\text { therapist }\end{array}$ & $\begin{array}{l}\text { No inter- } \\
\text { vention }\end{array}$ & $\begin{array}{l}\text { The proportion of } \\
\text { subjects who returned } \\
\text { to work was greater } \\
\text { in the training group. } \\
\text { Improvements in } \\
\text { walking distance, pain } \\
\text { reduction, and QoL } \\
\text { were observed in both } \\
\text { groups }\end{array}$ \\
\hline $\begin{array}{l}\text { Mecklen- } \\
\text { burg et } \\
\text { al. (2018) } \\
{[23]}\end{array}$ & $\begin{array}{l}\text { Individuals with } \\
\text { OA }\end{array}$ & $\begin{array}{l}162 \mathrm{fe}- \\
\text { males }\end{array}$ & 12 weeks & $\begin{array}{l}\text { Hinge } \\
\text { Health soft- } \\
\text { ware }\end{array}$ & $\begin{array}{l}\text { Private } \\
\text { coach }\end{array}$ & $\begin{array}{l}\text { Exercises with sen- } \\
\text { sor, training, CBT, } \\
\text { weight loss, and } \\
\text { remote psychologi- } \\
\text { cal support from a } \\
\text { private coach }\end{array}$ & $\begin{array}{l}\text { Self-care } \\
\text { training }\end{array}$ & $\begin{array}{l}\text { Improved pain, } \\
\text { improved physical per- } \\
\text { formance, stiffness, } \\
\text { reduced risk of surgery }\end{array}$ \\
\hline $\begin{array}{l}\text { Skrepnik } \\
\text { et al. } \\
\text { (2017) } \\
{[24]}\end{array}$ & $\begin{array}{l}\text { Individuals with } \\
\text { unilateral knee } \\
\text { osteoarthritis } \\
\text { and Hylan G-F } 20 \\
\text { injection }\end{array}$ & $\begin{array}{c}211 \\
\text { males }\end{array}$ & 12 weeks & $\begin{array}{l}\text { OA GO and } \\
\text { Jawbone } \\
\text { UP } 24 \\
\text { mobile ap- } \\
\text { plication }\end{array}$ & $\begin{array}{l}\text { The } \\
\text { patients }\end{array}$ & $\begin{array}{l}\text { Obtaining feedback } \\
\text { from activities } \\
\text { performed daily } \\
\text { and monthly (the } \\
\text { number of steps, } \\
\text { level of calories } \\
\text { consumed, \& } \\
\text { amount of sleep) } \\
\text { along with motiva- } \\
\text { tional messages }\end{array}$ & $\begin{array}{l}\text { No feed- } \\
\text { back }\end{array}$ & $\begin{array}{l}\text { Reduced pain, } \\
\text { increased mobility, } \\
\text { increased number } \\
\text { of stairs going up } \\
\text { and down, improved } \\
\text { performance in the } \\
\text { 6-minute walking test, } \\
\text { improved QoL }\end{array}$ \\
\hline $\begin{array}{c}\text { Li et al. } \\
\text { (2017) } \\
{[25]}\end{array}$ & $\begin{array}{l}\text { Individuals with } \\
\text { OA }\end{array}$ & $\begin{array}{l}34 \mathrm{fe}- \\
\text { males }\end{array}$ & 8 weeks & $\begin{array}{l}\text { Fitbit Flex } \\
\text { activity } \\
\text { tracker }\end{array}$ & $\begin{array}{l}\text { Telephone } \\
\text { consulta- } \\
\text { tion with a } \\
\text { physio- } \\
\text { therapist }\end{array}$ & $\begin{array}{l}\text { Using activity } \\
\text { tracker along with } \\
\text { weekly telephone } \\
\text { consultation with a } \\
\text { physiotherapist }\end{array}$ & $\begin{array}{l}\text { Similar } \\
\text { to the } \\
\text { experimen- } \\
\text { tal group } \\
\text { with a } \\
\text { one-month } \\
\text { delay in the } \\
\text { interven- } \\
\text { tion onset }\end{array}$ & $\begin{array}{l}\text { Improved moderate to } \\
\text { severe physical activity } \\
\text { in the experimental } \\
\text { group; improved pain, } \\
\text { daily living activities, } \\
\text { QoL, and health status }\end{array}$ \\
\hline $\begin{array}{c}\text { Bini et al. } \\
(2017) \\
{[26]}\end{array}$ & $\begin{array}{l}\text { Individuals with } \\
\text { total knee arthro- } \\
\text { plasty }\end{array}$ & $\begin{array}{l}50 \text { sub- } \\
\text { jects }\end{array}$ & 12 weeks & $\begin{array}{l}\text { Capture- } \\
\text { Proof } \\
\text { software }\end{array}$ & $\begin{array}{c}\text { The } \\
\text { patients }\end{array}$ & $\begin{array}{c}\text { Applying video } \\
\text { software on mobile }\end{array}$ & $\begin{array}{l}\text { Using } \\
\text { outpatient } \\
\text { physical } \\
\text { therapy }\end{array}$ & $\begin{array}{l}\text { Similar clinical results } \\
\text { for both groups }\end{array}$ \\
\hline $\begin{array}{l}\text { Lawford } \\
\text { et al. } \\
\text { (2018) } \\
{[27]}\end{array}$ & $\begin{array}{l}\text { Individuals with } \\
\text { OA }\end{array}$ & $\begin{array}{l}14 \text { sub- } \\
\text { jects }\end{array}$ & $\begin{array}{l}12 \text { weeks } \\
\text { (measure- } \\
\text { ment at } \\
\text { baseline and } \\
\text { after 3, and } 9 \\
\text { months) }\end{array}$ & $\begin{array}{c}\text { Online } \\
\text { interactive } \\
\text { automated } \\
\text { PCST } \\
\text { program }\end{array}$ & $\begin{array}{l}\text { Physio- } \\
\text { therapist; } \\
\text { via Skype }\end{array}$ & $\begin{array}{l}\text { Receiving treat- } \\
\text { ment program } \\
\text { via the internet } \\
\text { (app sections: self- } \\
\text { management train- } \\
\text { ing, using the PCST } \\
\text { program, talking to } \\
\text { physiotherapists) }\end{array}$ & $\begin{array}{l}\text { Receiving } \\
\text { treatment } \\
\text { programs } \\
\text { similar } \\
\text { to the } \\
\text { experimen- } \\
\text { tal group } \\
\text { without } \\
\text { access to } \\
\text { the PCST } \\
\text { program }\end{array}$ & $\begin{array}{l}\text { All participants in the } \\
\text { exercise group had a } \\
\text { significant reduction in } \\
\text { pain and a significant } \\
\text { improvement in } \\
\text { self-care }\end{array}$ \\
\hline $\begin{array}{l}\text { Bossen et } \\
\text { al. (2013) } \\
\text { [28] }\end{array}$ & $\begin{array}{l}\text { Individuals with } \\
\text { OA }\end{array}$ & $\begin{array}{l}199 \\
\text { sub- } \\
\text { jects }\end{array}$ & $\begin{array}{l}12 \text { weeks } \\
\text { (measure- } \\
\text { ment at } \\
\text { baseline and } \\
\text { after } 3 \text {, and } 12 \\
\text { months) }\end{array}$ & $\begin{array}{l}\text { Join2move } \\
\text { Website }\end{array}$ & $\begin{array}{l}\text { Without } \\
\text { supervisor } \\
\text { or sup- } \\
\text { porter }\end{array}$ & $\begin{array}{c}\text { Sign up for the } \\
\text { site and receive } \\
\text { weekly emails and } \\
\text { schedules }\end{array}$ & $\begin{array}{l}\text { No inter- } \\
\text { vention }\end{array}$ & $\begin{array}{l}\text { In the first 3-months, } \\
\text { an improvement in } \\
\text { physical performance } \\
\text { and self-efficiency } \\
\text { was observed in the } \\
\text { exercise group and no } \\
\text { changes in physical } \\
\text { activity were detected } \\
\text { in the exercise group }\end{array}$ \\
\hline
\end{tabular}




\begin{tabular}{|c|c|c|c|c|c|c|c|c|}
\hline 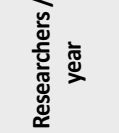 & Statistical Society & $\begin{array}{l}\text { Statis- } \\
\text { tical } \\
\text { Sample }\end{array}$ & Study Period & $\begin{array}{c}\text { Technology } \\
\text { Type }\end{array}$ & $\begin{array}{l}\text { Consul- } \\
\text { tant/Sup- } \\
\text { porter }\end{array}$ & $\begin{array}{l}\text { Experimental } \\
\text { Group Interven- } \\
\text { tions }\end{array}$ & $\begin{array}{l}\text { Control } \\
\text { Group } \\
\text { Interven- } \\
\text { tions }\end{array}$ & Results \\
\hline $\begin{array}{l}\text { Hussain et } \\
\text { al. (2017) } \\
\text { [29] }\end{array}$ & $\begin{array}{l}\text { Individuals with } \\
\text { total knee arthro- } \\
\text { plasty }\end{array}$ & $\begin{array}{l}320 \\
\text { sub- } \\
\text { jects }\end{array}$ & $\begin{array}{l}12 \text { weeks } \\
\text { (measure- } \\
\text { ment at } 4 \\
\text { weeks before } \\
\text { surgery, } \\
\text { immediately } \\
\text { before sur- } \\
\text { gery, } 12 \text { and } \\
52 \text { weeks after } \\
\text { surgery) }\end{array}$ & $\begin{array}{l}\text { Digital } \\
\text { orthopedic } \\
\text { reha- } \\
\text { bilitation } \\
\text { platform } \\
\text { (including } \\
2 \text { mobile } \\
\text { apps, activ- } \\
\text { ity tracker, } \\
\text { clinical } \\
\text { website) }\end{array}$ & $\begin{array}{l}\text { Clinical } \\
\text { care team } \\
\text { (surgeons } \\
\text { and phys- } \\
\text { iothera- } \\
\text { pists) }\end{array}$ & $\begin{array}{l}\text { Using digital } \\
\text { platform }\end{array}$ & $\begin{array}{l}\text { No inter- } \\
\text { vention }\end{array}$ & $\begin{array}{l}\text { Improved pain, range } \\
\text { of motion, and knee } \\
\text { function improved } \\
\text { QoL, improved physi- } \\
\text { cal and mental health } \\
\text { scores (i.e., stress, } \\
\text { anxiety, depression), } \\
\text { improved self-man- } \\
\text { agement, and ability to } \\
\text { actively bend the knee } \\
\text { in the training group. }\end{array}$ \\
\hline
\end{tabular}

PHYSICAL TREA TMENTS

activities. Studies have revealed that an inactive lifestyle (e.g., sitting for long periods) is a predictor of poor health outcomes [31]. In this regard, Li et al. (2017) investigated the effects of using an activity tracker for 8 weeks $(\geq 10$ minutes fast walking) along with telephone consultation with a physiotherapist once a week [32]. In their study, the control group received similar interventions to that of the exercise group with a one-month delay in the onset. Both research groups indicated moderate to high improvements in physical activity, pain, QoL, and health status, as well as increased daily living activity [25]. Interestingly, light activities, even at moderate levels (e.g., conducting daily living activities while standing or walking slowly), can be beneficial to health [32].

Moreover, Talbot et al. (2003) combined a pedometerbased walking program with self-management training for patients with knee OA [33]. Their results suggested a moderate increase in the daily number of going up and down the stairs $(23 \%)$ and the isometric strength of patients' quadriceps muscles (21\%), compared with the controls [33]. Compared to a pedometer, wearable devices, such as smartwatches and gadgets provide additional features, like the ability to track activity intensity and can provide performance diagram over time. These features enable individuals to follow specific goals with the awareness of their progress and provide real feedback on achieving the goals [34].

Better results were found in the studies in which supervision and support were provided and the patients were informed concerning their treatment process and progress [24]. Bossen et al. (2013) aimed to increase the patients' interaction and engagement with the treatment plan; accordingly, the program and treatment process was provided to the patients by weekly emails [28]. When each step was completed, the patient was allowed access to the next treatment step. This measure increased the patient's efforts to complete the steps to achieve rewards and reach the next intervention steps [28].

Therefore, designing an appropriate exercise program personalized to the patient's condition and symptoms, and capable of being implemented at home, is of great importance $[35,36]$. Additionally, targeting programs according to the individuals' characteristics and conditions is an essential principle of an exercise schedule. Limited studies have personalized the goals of physical activity, i.e., effective in promoting health, compared with public physical activity purposes [27].

Long-term adherence to exercises can habituate behavior in individuals. Based on the explored articles, employing digital technologies at different time intervals (2-12 weeks $\&$ even up to one year of follow-up) can promote health and improve self-care. In the study by Mecklenburg et al. (2018), exercise training was performed with sensor and remote psychological support by a private coach [23]. Besides, self-care training was conducted in 12 weeks. Their collected results reflected improvements in pain, physical function, and a decrease in the desire for surgery [23]. The cost of surgery in the United States is $\$ 40000$. This study indicated that the cost savings for surgery were estimated as $\$ 4340$ during one year, $\$ 4660$ over two years, and $\$ 7900$ over 5 years for the patients who participated in the digital care program, compared with the controls that only received self-care education articles [23].

Exercise therapy through DVDs, websites, or video software on mobiles allows patients to comfortably practice in their homes while watching a sports show [26, 35]. A study compared web-based and DVD-based exercise therapy in patients with hip osteoarthritis; the self- 
efficiency values were higher in the website group, i.e., important in behavior modification [35]. DVD-based exercise programs are only available by providing copied DVDs to the patients. Moreover, websites allow patients to have broader access to sports programs via the internet; however, there are concerns about interest in the internet among older patients [37].

Managing knee OA with exercises is a basis of conservative self-care for this chronic disease [37]. Despite the substantial literature supporting this recommendation, most physicians overlook exercises as part of patients' management plans. Generally, considering exercise by physicians to manage musculoskeletal disorders is scarce (\%14) [38]. The main reasons for the non-use of exercise prescription include the following: restricted visiting time of patients, and the lack of exercise training in medical schools, resulting in insufficient basic knowledge of exercise training $[39,40]$. Patients with OA stated that their main reason for not exercising and improving their condition was the lack of receiving exercise suggestions from their physician [39].

Web-based and smartphone applications as well as the internet can be successfully used for self-management and rehabilitation interventions in patients with knee OA [41]. The patients who received personalized and interactive instructions to improve pain, stiffness, and physical performance were satisfied with this approach [42, 43]. Applying the internet for health and physical activity interventions has the potential to reduce costs, improve health, and satisfy users [44]. Brooks et al. (2014) in their prospective study designed the first comprehensive web-based system (Therapeutic Exercise Resource Center [TERC]) to evaluate, prescribe, monitor, and adjust exercise therapy programs for patients with OA [28]. In this system, a personalized program, including strength, flexibility, and aerobic exercises is designed based on the patient-entered data, and developed to improve neuromuscular disorders, knee OA symptoms, and general health [45].

TERC can be used by healthcare providers to promote exercise among patients with knee OA [44]. The clinical features of the TERC program include the following: the ability to determine the health level of individuals; to administer a personalized exercise program for each participant, and to provide high-quality animations that present the correct pattern of exercise movements to the patients with OA. Live modeling or the video training of exercises significantly reduces the number of functional errors, compared to the mere use of printed tables of exercise program. Patients' confidence increases respecting the ability to correctly perform the sports prescriptions and the odds of adherence to exercise programs. In this study, $>90 \%$ of patients reported that sports animations were useful and easy to imitate [45].

Using mobile health applications has the potential to improve the patient's therapeutic outcomes. Mobile health programs are beneficial tools in weight loss programs [46]. Mobile phones are considered as mobile technologies, one of which is smartphones [47]. Some features of mobile phones include sensors, such as GPS, accelerometer, Wi-Fi, and Bluetooth, as well as wireless communication with apparatus, like heart rate belts [48, 49].

Schoeppe et al. (2016) argued that the effectiveness of smartphone applications with wearable devices is greater than that of smartphone applications alone [50]. However, no articles compared the distinct roles of wearable devices with smartphone apps on physical activity and adherence to the sport. Hussain et al. (2017) evaluated the effects of using a home-based digital platform after surgery. Their results demonstrated improved pain, range of motion, and knee function; improved QoL and biopsychological health scores (i.e., stress, anxiety, depression), and improved self-management and the ability to actively bend the knee [29]. Such services not only provide access to post-surgical rehabilitation to the patients in the relatively remote geographic areas but also reduce transportation costs and time required for the healthcare systems and the patients, as well as prolong rehabilitation interventions.

\section{Conclusion}

Considering the increasing prevalence of knee pain among the population and the rising cost of treatment, the necessity of training individuals on prevention, treatment, and self-care has been overemphasized. Furthermore, the role of digital technologies and media is becoming more noticeable. This is due to the high cost of developing physical platforms for health education and information provision in the field of health, as well as the advancements of technologies and their increasing use in individuals' lives. The present study data indicated that decreased mobility in patients with knee OA may adversely impact their QoL and pain. Motivating patients to walk may increase mobility which can reduce these negative effects.

Applying digital technologies provides a significant improvement in motor parameters and reduces pain in patients with knee OA and TKA. Moreover, the ability of patients and physicians to use digital technologies in the treatment and control of diseases is of importance. However, further studies are required to increase the accep- 
tance rate of using digital technologies for treatment and self-care by sports therapists, physicians, and patients.

\section{Ethical Considerations}

\section{Compliance with ethical guidelines}

All ethical principles are considered in this article. The participants were informed of the purpose of the research and its implementation stages.

\section{Funding}

This research received no specific grant from funding agencies in the public, commercial, or non-profit sectors.

\section{Authors' contributions}

All authors equally contributed in preparing this article.

\section{Conflict of interest}

The authors declared no conflicts of interest.

\section{References}

[1] Murphy L, Schwartz TA, Helmick CG, Renner JB, Tudor $\mathrm{G}$, Koch $\mathrm{G}$, et al. Lifetime risk of symptomatic knee osteoarthritis. Arthritis and Rheumatism. 2008; 59(9):1207-13. [DOI:10.1002/art.24021] [PMID] [PMCID]

[2] Lawrence RC, Felson DT, Helmick CG, Arnold LM, Choi $\mathrm{H}$, Deyo RA, et al. Estimates of the prevalence of arthritis and other rheumatic conditions in the United States: Part II. Arthritis \& Rheumatism. 2008; 58(1):26-35. [DOI:10.1002/ art.23176] [PMID] [PMCID]

[3] Hootman JM, Helmick CG, Barbour KE, Theis KA, Boring MA. Updated projected prevalence of self-reported doctordiagnosed arthritis and arthritis-attributable activity limitation among US adults, 2015-2040. Arthritis \& Rheumatology. 2016; 68(7):1582-7. [DOI:10.1002/art.39692] [PMID] [PMCID]

[4] Hubertsson J, Petersson IF, Thorstensson CA, Englund M. Risk of sick leave and disability pension in working-age women and men with knee osteoarthritis. Annals of the Rheumatic Diseases. 2013; 72(3):401-5. [DOI:10.1136/annrheumdis-2012-201472] [PMID]

[5] Reginster J-Y, Reiter-NiesertS, Bruyère O, Berenbaum F, Brandi M-L, Branco J, et al. Recommendations for an update of the 2010 European regulatory guideline on clinical investigation of medicinal products used in the treatment of osteoarthritis and reflections about related clinically relevant outcomes: Expert consensus statement. Osteoarthritis and Cartilage. 2015 23(12):2086-93. [DOI:10.1016/j.joca.2015.07.001] [PMID]

[6] Smink AJ, Dekker J, Vliet Vlieland TPM, Swierstra BA, Kortland $\mathrm{JH}, \mathrm{Bijlsma} \mathrm{JWJ}$, et al. Health care use of patients with osteoar- thritis of the hip or knee after implementation of a stepped-care strategy: An observational study. Arthritis Care \& Research 2014; 66(6):817-27. [DOI:10.1002/acr.22222] [PMID]

[7] Booth J, Moseley GL, Schiltenwolf M, Cashin A, Davies M, Hübscher M. Exercise for chronic musculoskeletal pain: A biopsychosocial approach. Musculoskeletal Care. 2017; 15(4):413-21. [DOI:10.1002/msc.1191] [PMID]

[8] Singh JA, Yu S, Chen L, Cleveland JD. Rates of total joint replacement in the United States: Future projections to 2020-2040 using the National Inpatient Sample. The Journal of Rheumatology. 2019; 46(9):1134-40. [DOI:10.3899/jrheum.170990] [PMID]

[9] Kurtz S, Ong K, Lau E, Mowat F, Halpern M. Projections of primary and revision hip and knee arthroplasty in the United States from 2005 to 2030. The Journal of Bone and Joint Surgery. American Volume. 2007; 89(4):780-5. [DOI:10.2106/00004623-200704000-00012] [PMID]

[10] Finch E, Walsh M, Thomas SG, Woodhouse LJ. Functional ability perceived by individuals following total knee arthroplasty compared to age-matched individuals without knee disability. Journal of Orthopaedic \& Sports Physical Therapy. 1998; 27(4):255-63. [DOI:10.2519/jospt.1998.27.4.255] [PMID]

[11] Saki F, Sedaghati P, Aghamohamadi N. [Distal muscle imbalance in girls with and without medial knee displacement during double leg squat (Persian)]. Journal of Sabzevar University of Medical Sciences. 2018; 25(4):537-45. http:/ /jsums. medsab.ac.ir/article_1099_en.html

[12] Saki F, Madhoush M. Effect of eight weeks plyometric training on hip strength in female athletes with dynamic knee valgus. Journal for Research in Sport Rehabilitation. 2019; 6(12):9-10 https:// www.sid.ir/en/journal/ViewPaper.aspx?ID=748617

[13] White DK, Tudor-Locke C, Zhang Y, Fielding R, LaValley $\mathrm{M}$, Felson DT, et al. Daily walking and the risk of incident functional limitation in knee osteoarthritis: An observational study. Arthritis Care \& Research. 2014; 66(9):1328-36. [DOI:10.1002/acr.22362] [PMID] [PMCID]

[14] Statista. Number of smartphone users worldwide from 2014 to 2020 (in billions); 2016. https:/ / www.statista.com/ search/?q=Number+of+smartphone+users+worldwide+fr $o m+2014+$ to $+2020+\& q K a t=$ search

[15] Aitken D, Buchbinder R, Jones G, Winzenberg T. Interventions to improve adherence to exercise for chronic musculoskeletal pain in adults. Australian Family Physician. 2015; 44(1-2):39-42. [PMID]

[16] Lee I-M, Shiroma EJ, Lobelo F, Puska P, Blair SN, Katzmarzyk PT, et al. Effect of physical inactivity on major non-communicable diseases worldwide: An analysis of burden of disease and life expectancy. Lancet. 2012; 380(9838):219-29. [DOI:10.1016/S0140-6736(12)61031-9] [PMCID]

[17] Sepah SC, Jiang L, Peters AL. Long-term outcomes of a Webbased diabetes prevention program: 2-year results of a singlearm longitudinal study. Journal of Medical Internet Research 2015; 17(4):e92. [DOI:10.2196/jmir.4052] [PMID] [PMCID]

[18] Espie CA, Kyle SD, Williams C, Ong JC, Douglas NJ Hames $\mathrm{P}$, et al. A randomized, placebo-controlled trial of online cognitive behavioral therapy for chronic insomnia disorder delivered via an automated media-rich web application. Sleep. 2012; 35(6):769-81. [DOI:10.5665/sleep.1872] [PMID] [PMCID] 
[19] Joshi GP, Ogunnaike BO. Consequences of inadequate postoperative pain relief and chronic persistent postoperative pain. Anesthesiology Clinics of North America. 2005; 23(1):21-36. [DOI:10.1016/j.atc.2004.11.013] [PMID]

[20] de Morton NA. The PEDro scale is a valid measure of the methodological quality of clinical trials: a demographic study. Australian Journal of Physiotherapy. 2009; 55(2):12933. [DOI:10.1016/S0004-9514(09)70043-1]

[21] Moher D, Shamseer L, Clarke M, Ghersi D, Liberati A, Petticrew $\mathrm{M}$, et al. Preferred reporting items for systematic review and meta-analysis protocols (PRISMA-P) 2015 statement. Systematic Reviews. 2015; 4(1):1. [DOI:10.1186/2046-4053-4-1]

[22] Eichler S, Salzwedel A, Rabe S, Mueller S, Mayer F, Wochatz $\mathrm{M}$, et al. The effectiveness of telerehabilitation as a supplement to rehabilitation in patients after total knee or hip replacement: Randomized controlled trial. JMIR Rehabilitation and Assistive Technologies. 2019; 6(2):e14236. [DOI:10.2196/14236] [PMID] [PMCID]

[23] Mecklenburg G, Smittenaar P, Erhart-Hledik JC, Perez DA, Hunter S. Effects of a 12-week digital care program for chronic knee pain on pain, mobility, and surgery risk: Randomized controlled trial. Journal of Medical Internet Research. 2018; 20(4):e156. [DOI:10.2196/jmir.9667] [PMID] [PMCID]

[24] Skrepnik N, Spitzer A, Altman R, Hoekstra J, Stewart J, Toselli R. Assessing the impact of a novel smartphone application compared with standard follow-up on mobility of patients with knee osteoarthritis following treatment with Hylan GF 20: A randomized controlled trial. JMIR Mhealth and Uhealth. 2017;5(5):e64. [DOI:10.2196/mhealth.7179] [PMID] [PMCID]

[25] Li LC, Sayre EC, Xie H, Clayton C, Feehan LM. A community-based physical activity counselling program for people with knee osteoarthritis: Feasibility and preliminary efficacy of the track-OA study. JMIR Mhealth and Uhealth. 2017; 5(6):e86. [DOI:10.2196/mhealth.7863] [PMID] [PMCID]

[26] Bini SA, Mahajan J. Clinical outcomes of remote asynchronous telerehabilitation are equivalent to traditional therapy following total knee arthroplasty: A randomized control study. Journal of Telemedicine and Telecare. 2017; 23(2):23947. [DOI:10.1177/1357633X16634518] [PMID]

[27] Lawford BJ, Hinman RS, Kasza J, Nelligan R, Keefe F, Rini $\mathrm{C}$, et al. Moderators of effects of internet-delivered exercise and pain coping skills training for people with knee osteoarthritis: Exploratory analysis of the impact randomized controlled trial. Journal of Medical Internet Research. 2018; 20(5):e10021. [DOI:10.2196/10021] [PMID] [PMCID]

[28] Bossen D, Veenhof C, Van Beek KE, Spreeuwenberg PM, Dekker J, De Bakker DH. Effectiveness of a web-based physical activity intervention in patients with knee and/or hip osteoarthritis: Randomized controlled trial. Journal of Medical Internet Research. 2013; 15(11):e257. [DOI:10.2196/ jmir.2662] [PMID] [PMCID]

[29] Hussain MS, Li J, Brindal E, van Kasteren Y, Varnfield M, Reeson A, et al. Supporting the delivery of total knee replacements care for both patients and their clinicians with a mobile app and web-based tool: Randomized controlled trial protocol. JMIR Research Protocols. 2017; 6(3):e32. [DOI:10.2196/resprot.6498] [PMID] [PMCID]

[30] Gyurcsik NC, Brawley LR, Spink KS, Brittain DR, Fuller DL, Chad K. Physical activity in women with arthritis: Examining perceived barriers and self-regulatory efficacy to cope. Arthritis Care \& Research. 2009; 61(8):1087-94. [DOI:10.1002/art.24697] [PMID]

[31] Thorp AA, Owen N, Neuhaus M, Dunstan DW. Sedentary behaviors and subsequent health outcomes in adults: a systematic review of longitudinal studies, 1996-2011. American Journal of Preventive Medicine. 2011; 41(2):207-15. [DOI:10.1016/j.amepre.2011.05.004] [PMID]

[32] Li L, Kopec JA, Cibere J, Esdaile J, Sayre E. British columbia osteoarthritis survey. Arthritis Research Centre of Canada. 2008. https://arthritis.rehab.med.ubc.ca/files/2011/08/ BCOASurvey.pdf

[33] Talbot LA, Gaines JM, Huynh TN, Metter EJ. A home-based pedometer-driven walking program to increase physical activity in older adults with osteoarthritis of the knee: A preliminary study. Journal of the American Geriatrics Society. 2003; 51(3):387-92. [DOI:10.1046/j.1532-5415.2003.51113.x] [PMID]

[34] Lyons EJ, Lewis ZH, Mayrsohn BG, Rowland JL. Behavior change techniques implemented in electronic lifestyle activity monitors: A systematic content analysis. Journal of Medical Internet Research. 2014; 16(8):e192. [DOI:10.2196/ jmir.3469] [PMID] [PMCID]

[35] Uesugi Y, Koyanagi J, Takagi K, Yamaguchi R, Hayashi S, Nishii T. Exercise therapy interventions in patients with hip osteoarthritis: Comparison of the effects of DVD and website-based interventions. JMIR Rehabilitation and Assistive Technologies. 2018; 5(1):e10. [DOI:10.2196/rehab.8251] [PMID] [PMCID]

[36] Harmelink KEM, Zeegers AVCM, Tönis TM, Hullegie W, Nijhuis-van der Sanden MWG, Staal JB. The effectiveness of the use of a digital activity coaching system in addition to a two-week home-based exercise program in patients after total knee arthroplasty: Study protocol for a randomized controlled trial. BMC Musculoskeletal Disorders. 2017; 18(1):290. [DOI:10.1186/s12891-017-1647-5] [PMID] [PMCID]

[37] Bennell KL, Hinman RS. A review of the clinical evidence for exercise in osteoarthritis of the hip and knee. Journal of Science and Medicine in Sport. 2011; 14(1):4-9. [DOI:10.1016/j. jsams.2010.08.002] [PMID]

[38] Freburger JK, Carey TS, Holmes GM, Wallace AS, Castel LD, Darter JD, et al. Exercise prescription for chronic back or neck pain: Who prescribes it? Who gets it? What is prescribed? Arthritis and Rheumatism. 2009; 61(2):192-200. [DOI:10.1002/art.24234] [PMID] [PMCID]

[39] Der Ananian C, Wilcox S, Saunders R, Watkins K, Evans A. Factors that influence exercise among adults with arthritis in three activity levels. Preventing Chronic Disease. 2006; 3(3):A81. [PMCID]

[40] Peterson JA. Get moving! Physical activity counseling in primary care. Journal of the American Academy of Nurse Practitioners. 2007; 19(7):349-57. [DOI:10.1111/j.1745-
[D 7599.2007.00239.x] [PMID]

[41] Pietrzak E, Cotea C, Pullman S, Nasveld P. Self-management and rehabilitation in osteoarthritis: Is there a place for internet-based interventions? Telemedicine and E-health 2013; 19(10):800-5. [DOI:10.1089/tmj.2012.0288] [PMID]

[42] Jevsevar DS. Treatment of osteoarthritis of the knee: Evidence-based guideline. Journal of the American Academy of Orthopaedic Surgeons. 2013; 21(9):571-6. [DOI:10.5435/00124635-201309020-00008] [PMID] 
[43] Sciamanna CN, Harrold LR, Manocchia M, Walker NJ, Mui $\mathrm{S}$. The effect of web-based, personalized, osteoarthritis quality improvement feedback on patient satisfaction with osteoarthritis care. American Journal of Medical Quality. 2005; 20(3):127-37. [DOI:10.1177/1062860605274518] [PMID]

[44] Fransen M, McConnellS, Harmer AR, Van der Esch M,Simic $\mathrm{M}$, et al. Exercise for osteoarthritis of the knee. Cochrane Database of Systematic Reviews. 2015; 1:CD004376. [DOI:10.1002/14651858.CD004376.pub3] [PMID]

[45] Brooks MA, Beaulieu JE, Severson HH, Wille CM, Cooper D, Gau JM, et al. Web-based therapeutic exercise resource center as a treatment for knee osteoarthritis: A prospective cohort pilot study. BMC Musculoskeletal Disorders. 2014; 15:158. [DOI:10.1186/1471-2474-15-158] [PMID] [PMCID]

[46] Mateo GF, Granado-Font E, Ferré-Grau C, Montaña-Carreras X. Mobile phone apps to promote weight loss and increase physical activity: A systematic review and meta-analysis. Journal of Medical Internet Research. 2015; 17(11):e253. [DOI:10.2196/jmir.4836] [PMID] [PMCID]

[47] Luxton DD, McCann RA, Bush NE, Mishkind MC, Reger GM. mHealth for mental health: Integrating smartphone technology in behavioral healthcare. Professional Psychology: Research and Practice. 2011; 42(6):505-12. [DOI:10.1037/a0024485]

[48] Farrington C, Aristidou A, Ruggeri K. Mhealth and global mental health: Still waiting for the $\mathrm{mH} 2$ wedding? Globalization and Health. 2014; 10:17. [DOI:10.1186/1744-8603-1017] [PMID] [PMCID]

[49] Gravenhorst F, Muaremi A, Bardram J, Grünerbl A, Mayora $\mathrm{O}$, Wurzer G, et al. Mobile phones as medical devices in mental disorder treatment: An overview. Personal and Ubiquitous Computing. 2015; 19(2):335-53. [DOI:10.1007/ s00779-014-0829-5]

[50] Schoeppe S, Alley S, Van Lippevelde W, Bray NA, Williams SL, Duncan MJ, et al. Efficacy of interventions that use apps to improve diet, physical activity and sedentary behaviour: A systematic review. International Journal of Behavioral $\mathrm{Nu}$ trition and Physical Activity. 2016; 13(1):127. [DOI:10.1186/ s12966-016-0454-y] [PMID] [PMCID] 